\title{
A STUDY ON THE FACTORS AFFECTING HEALTH AND ECONOMIC ACTIVITIES OF WORK ENVIRONMENT IN MANUFACTURING INDUSTRY
}

\author{
Kil Yong Choi ${ }^{1}$, Jinsu Kim² \& Seong min $\operatorname{Han}^{3}$
}

Abstract-Objective: The manufacturing industry has seen the highest number of industrial disasters, making it an important task to study how industry workers understand the safety environment in order to prevent industrial accidents.

Methods: Participants were 1,123 men, who were manufacturing employees who responded to the 2015 PSWCI panel report. Participants provided self-reported health data, which were then analyzed for their changes in relation to employment condition during the course of one year. Statistical analyses were performed using SAS version 9.4.

Results: Data analysis showed that the manufacturing industry had differences in economic activity and health conditions based on employee's conditions. Dynamic change aspects of manufacturing industry condition had differences between sex and cases where going back and forth between temporary condition and unemployment status had higher percentage in male.

Conclusions: Results of this study may serve as a reference in introducing legislation to improve the safety of the work environment at manufacturing industries.

Keywords: health, economic activity, work environment, manufacturing industry, industry, manufacturing

\section{INTRODUCTION}

In the 2000s, Korea considered in earnest the working conditions in the manufacturing environment relating to workers' physical and psychological health. Some of the factors that influence workplace safety (knowledge, working environment, motivation, etc.) directly relate to the workers and are thus important for preventing industrial accidents. There are also external safety factors unique to the modern society's workplace, such as sleep disturbances due to shift work or night shifts, that result from the increasing number of shift workers in an unstable work environment and in work environments that are characteristic of firms are in today's workplace (1-5).

If these harmful conditions persist at the working environment, Korean society may sustain a loss of workers and corporations, which may further adversely affect its socioeconomic environment. It is thus necessary to improve the working environment (6).

This study suggested that workers' chronic diseases could act as a physical and psychological stress factor that affects their participation in economic activities. As a result, preventive research should be conducted to reduce the barriers to these workers' behaviors (7-9).

\subsection{Purpose of study}

The purpose of this study was to improve the working environment for Korean workers and the general labor market by using the "2015 Work Environment Survey" and to examine the effects of the working conditions of the manufacturing industry. Through a data analysis, the relation of the following three major factors with health deterioration was also analyzed: workers' length of time in manufacturing and health status (current chronic diseases, weekly average exercise, current smoking, daily smokers, current drinking, number of drinking, etc.), unhealthy work-related habits (e.g., smoking cigarettes, drinking), and positive lifestyle that enhances individual health.

\subsection{Preliminary research and hypothesis}

Previous studies have shed light on how the manufacturing working environment is associated with deteriorated health in workers in developed countries and analyzed how this relationship differs across countries depending on regional characteristics, diseases, and poverty $(10,11)$. A variety of risk factors have also given rise to chronic diseases in manufacturing workers (12). In Korea, studies have confirmed the global impact of chronic diseases on the economy and recognized the need

\footnotetext{
${ }^{1}$ Department of Environmental Engineering, Pusan National University, Busan, Korea.

${ }^{2}$ Department of Environmental Engineering, Pusan National University, Busan, Korea.

${ }^{3}$ Department of Social Welfare, Kyungwoon university, Gyeongsangbuk-do Province, Korea
} 
to prevent occupational chronic diseases, as ergonomic stress seems to have led to the increase of labor-induced musculoskeletal diseases (13).

\section{MATERIALS AND METHODS}

\subsection{Target population}

This study used survey data from Panel Study of Workers' Compensation Insurance (PSWCI) 2015. From the survey respondents (1422 men and 282 women), the study narrowed in on male participants and examined their demographic characteristics, compensation services, health and quality of life, general household items, and other pertinent information. The study population consisted of 1,123 male workers engaged in construction and manufacturing services, including those who were under age $20(\mathrm{~N}=40,3.6 \%), 20-30$ years of age $(\mathrm{N}=150,13.4 \%), 30-40$ years of age $(\mathrm{N}=297,26.4 \%), 40-50$ years of age $(\mathrm{N}=377,33.6 \%)$, and those over 60 years of age $(\mathrm{N}=259,23.0 \%)$

\subsection{Demographics}

Among the 1,123 study subjects, this is the breakdown of the province in which they worked: Daegu / Gyeongbuk $(\mathrm{N}=165$, $14.7 \%)$, Gangwon $(\mathrm{N}=58,5.2 \%)$, Gyeongnam / Ulsan $(\mathrm{N}=144,12.8 \%)$, Gyeonggi $(\mathrm{N}=321,28.6 \%)$, Incheon $(\mathrm{N}=124,11.0 \%)$, Jeolla $(\mathrm{N}=144,12.8 \%)$, and Chungcheong $(\mathrm{N}=140,12.5 \%)$. No manufacturing, construction, and service respondents were employed in Seoul and Busan.

With respect to educational level, except in Gyeonggi Province $(\mathrm{N}=207,18.4 \%)$, the majority of respondents were high school graduates $(\mathrm{N}=522,46.5 \%)$, followed by those who attended some college but did not graduate $(\mathrm{N}=209,18.6 \%)$ and finally college graduates $(\mathrm{N}=185,16.5 \%)$.

In case of accident type $(\mathrm{N}=1027,91.5 \%)$, disease has distributed the $(\mathrm{N}=96,8.5 \%)$, Respondents that a disable was higher in the presence $(\mathrm{N}=938,83.5 \%)$. In the case of no accident $(\mathrm{N}=185,16.5 \%)$, it was low.

\subsection{Analysis}

Data analysis was performed using SAS version 9.4 (SAS Institute Inc., Cary, NC, USA) and logistic regression model to evaluate the relationship between the length of time workers have been in the manufacturing industry and any chronic disease that occurred before an industrial accident. In addition, a 95\% confidence interval (CI) and odds ratios (ORs) showed significant differences between the two groups ( $p<0.05$ for adjusted variables of sex, age, educational attainment, and region); the probability ratio was then calculated.

\section{RESULTS}

\subsection{Working period and working environment $(N=1,123)$}

Of the 1,123 male workers, $284(36.6 \%)$ have been in the manufacturing industry for less than one month, $289(25.7 \%)$ have been in the industry for six months to a year, $86(7.7 \%)$ for one to three years, $44(3.9 \%)$ and $74(6.6 \%)$ for more than five years. This suggests that the lifespan of personnel in the manufacturing working environment is short. Further, $80 \%$ of these manufacturing employees experienced an industrial accident within one year of employment in the working environment $(\mathrm{p}=$ 0.0001). Subsequent to the industrial accident, $21.9 \%$ returned to the original job (continuous) and $0.5 \%$ returned to the original job (new); others found reemployment (33.3\% continuous, $15.8 \%$ new), became unemployed family workers $(1.7 \%$ new, $0.6 \%$ continuous), or simply unemployed (3.3\%) and unemployed people (17.1\%). When classified into two kinds, p values, 0.0004 and 0.0045 respectively, are significant [Table 1].

Table 1. Association between individual characteristics and working conditions

\begin{tabular}{llll}
\hline & & $n=1,123(\%)$ & $p$-value \\
\hline \hline & Less than a month & $284(36.6)$ & \\
& One to two months & $84(10.8)$ & \\
& Two to three months & $49(6.3)$ & \\
Working period & Four to five months & $23(3.0)$ & \\
& Five to six months & $42(5.4)$ & \\
& Six months to one year & $91(11.7)$ & \\
& One to two years & $53(6.8)$ & \\
& Two to three years & $33(4.2)$ & \\
\hline
\end{tabular}




\begin{tabular}{|c|c|c|c|}
\hline & More than Four years & $87(11.2)$ & \\
\hline \multirow{6}{*}{ Type 3 of EA } & Back to work & $174(22.4)$ & \multirow{6}{*}{0.0004} \\
\hline & Re-employment & $381(49.1)$ & \\
\hline & Self-employed & $57(7.3)$ & \\
\hline & Unpaid family workers & $6(0.8)$ & \\
\hline & Dismissal & $26(3.3)$ & \\
\hline & Economically active population & $133(17.1)$ & \\
\hline \multirow{10}{*}{ Type 4 of EA } & Back to work (continue) & $170(21.9)$ & \multirow{10}{*}{0.0045} \\
\hline & Back to work (new) & $4(0.5)$ & \\
\hline & Re-employment (continue) & $258(33.3)$ & \\
\hline & Re-employment (new) & $123(15.8)$ & \\
\hline & Self-employed (continue) & $44(5.7)$ & \\
\hline & Self-employed (new) & $13(1.7)$ & \\
\hline & Unpaid family workers (continue) & $5(0.6)$ & \\
\hline & Unpaid family workers (new) & $1(0.1)$ & \\
\hline & Dismissal & $26(3.3)$ & \\
\hline & Economically active population & $133(17.1)$ & \\
\hline
\end{tabular}

\subsection{Health and quality of life $(N=906)$}

Data on the health and quality of life of manufacturing men were statistically significant $(\mathrm{p}=0.0194)$, but not in detail, compared with those without chronic disease (36.8\%). The mean number of exercise days per week was 5-6 days, 51\%, 70\%, and the rest were $30 \sim 40$, respectively $(\mathrm{p}=0.0024)$. This was statistically significant in $43.4 \%$ and $43.1 \%$ of smoking and drinking, respectively $(\mathrm{p}=0.0001,0.0001)$. Among them, the number of smoking was not influenced by the frequency of drinking, but the frequency of drinking was $43-45 \%$ in monthly and weekly frequency $(\mathrm{p}=0.0006)$ [Table 2].

Table 2. Association between industrial workers and health problems

\begin{tabular}{|c|c|c|c|c|}
\hline & & $\begin{array}{l}N O \\
n=518(\%) \\
\end{array}$ & $\begin{array}{l}Y E S \\
n=388(\%) \\
\end{array}$ & $p$-value \\
\hline \multirow{2}{*}{ Current chronic disease } & yes & $165(63.2)$ & $96(36.8)$ & \multirow{2}{*}{0.0194} \\
\hline & no & $353(54.7)$ & $292(45.3)$ & \\
\hline \multirow{7}{*}{ Exercise level (days per week) } & 1 day & $45(57.7)$ & $33(42.3)$ & \multirow{7}{*}{0.0024} \\
\hline & 2 days & $43(53.1)$ & $38(46.9)$ & \\
\hline & 3 days & $54(63.5)$ & $31(36.5)$ & \\
\hline & 4 days & $21(56.8)$ & $16(43.2)$ & \\
\hline & 5 days & $28(49.1)$ & $29(50.9)$ & \\
\hline & 6 days & $7(30.4)$ & $16(69.6)$ & \\
\hline & 7 days & $38(64.4)$ & $21(35.6)$ & \\
\hline \multirow{2}{*}{ Current smoking } & yes & $279(56.6)$ & $214(43.4)$ & \multirow{2}{*}{$<.0001$} \\
\hline & no & $239(57.9)$ & $174(42.1)$ & \\
\hline \multirow{2}{*}{ Current drinking } & yes & $377(56.9)$ & $286(43.1)$ & \multirow{2}{*}{0.0001} \\
\hline & no & $141(58.0)$ & $102(42.0)$ & \\
\hline \multirow{5}{*}{ Frequency of drinking } & $<$ Once a month & $30(75)$ & $10(25)$ & \multirow{5}{*}{0.0006} \\
\hline & Twice or thrice a month & $30(54.5)$ & $25(45.5)$ & \\
\hline & Weekly or semiweekly & $90(54.2)$ & $76(45.8)$ & \\
\hline & triweekly triweekly & $178(56.5)$ & $137(43.5)$ & \\
\hline & Daily & $49(56.3)$ & $38(43.7)$ & \\
\hline
\end{tabular}




\subsection{Quality of life and general characteristics of households $(N=906)$}

As a result of considering the quality of life of the manufacturing men and the characteristics of the individual of questionnaire, the affirmative in the perception of their own lives showed a tendency to be as high as $72 \%$ and statistically significant $(\mathrm{P}=$ 0.008). When negative thoughts on their behavior were high, they were $63 \%(\mathrm{P}=0.0511)$. In the external activities of the number of meetings (neighbors) and the number of meetings (religious gatherings), $46 \%$ and $85 \%$, respectively, $(\mathrm{P}=0.0143$, 0.046). In addition, there was a significant difference between the two groups. In addition, they are respectively in the final education (graduation status), marital status, difficulty in performing daily living (occupational activities), and leisure activities $(\mathrm{p}=0.0185,0.0336,0.0127)$ [Table 3].

Table 3. Association between quality of life and general characteristics of household

\begin{tabular}{|c|c|c|c|c|}
\hline & & $\begin{array}{l}N O \\
n=518(\%) \\
\end{array}$ & $\begin{array}{l}Y E S \\
n=388(\%) \\
\end{array}$ & $p$-value \\
\hline \multirow{4}{*}{$\begin{array}{l}\text { Current, } \\
\text { feel in your life }\end{array}$} & Not at all & $55(10.6)$ & $25(6.4)$ & \multirow{4}{*}{0.008} \\
\hline & Several times & $139(26.8)$ & $85(21.9)$ & \\
\hline & Considerable period of time & $220(42.5)$ & $205(52.9)$ & \\
\hline & Always & $104(20.1)$ & $73(18.8)$ & \\
\hline \multirow{5}{*}{$\begin{array}{l}\text { Second time, } \\
\text { Feel in your life }\end{array}$} & Not at all & $5(1.0)$ & $2(0.5)$ & \multirow{5}{*}{0.0511} \\
\hline & Not as essential & $58(11.2)$ & $32(8.2)$ & \\
\hline & Several times & $194(37.4)$ & $177(45.6)$ & \\
\hline & Considerable period of time & $218(42.1)$ & $157(40.5)$ & \\
\hline & Always & $43(8.3)$ & $20(5.2)$ & \\
\hline \multirow{5}{*}{ Meeting (Neighbor) } & Not at all & $216(41.7)$ & $179(46.2)$ & \multirow{5}{*}{0.0143} \\
\hline & One in six months & $37(7.1)$ & $33(8.5)$ & \\
\hline & Once a month & $77(14.9)$ & $68(17.5)$ & \\
\hline & Once a week & $124(23.9)$ & $85(21.9)$ & \\
\hline & Always & $64(12.4)$ & $23(5.9)$ & \\
\hline \multirow{6}{*}{$\begin{array}{l}\text { Meeting } \\
\text { gatherings) }\end{array}$} & Not at all & $420(81.0)$ & $330(85.1)$ & \multirow{6}{*}{0.046} \\
\hline & Less than once a month & $19(3.7)$ & $18(4.6)$ & \\
\hline & ${ }_{s}$ Once a month & $7(1.4)$ & $2(0.5)$ & \\
\hline & About two or three times a month & $7(1.4)$ & $6(1.5)$ & \\
\hline & Once a week & $45(8.6)$ & $29(7.5)$ & \\
\hline & At least twice a week & $20(3.9)$ & $3(0.8)$ & \\
\hline \multirow{3}{*}{ Education } & School graduation & $416(97.7)$ & $308(97.7)$ & \multirow{3}{*}{0.0185} \\
\hline & In school & $3(0.7)$ & $11(0.7)$ & \\
\hline & Dropout & $7(1.6)$ & $3(1.6)$ & \\
\hline \multirow{5}{*}{ Marriage } & Single & $20(4.5)$ & $18(5.4)$ & \multirow{5}{*}{0.0336} \\
\hline & Married, mate & 403(91.4) & $287(85.6)$ & \\
\hline & separation & $1(0.2)$ & $0(0.0)$ & \\
\hline & Divorce & $3(0.7)$ & $3(0.9)$ & \\
\hline & Death of spouse & $14(3.2)$ & $27(8.1)$ & \\
\hline \multirow{5}{*}{$\begin{array}{l}\text { Difficulties in the } \\
\text { performance in our } \\
\text { daily lives (work } \\
\text { activity) }\end{array}$} & Always & $37(7.1)$ & $17(4.4)$ & \multirow{5}{*}{0.0127} \\
\hline & Considerable period of time & $90(17.4)$ & $42(10.8)$ & \\
\hline & Several times & $61(11.8)$ & $58(14.9)$ & \\
\hline & Not as essential & $141(27.2)$ & $109(28.1)$ & \\
\hline & Not at all & $189(36.5)$ & $162(41.8)$ & \\
\hline
\end{tabular}

3.4 Job characteristics $(N=777)$

Of the research participants examined in this study, $13.1 \%$ were non-standard wage workers, $3.7 \%$ had employees, $34.6 \%$ were self-employed workers without employees, and the rest were unpaid family workers $(\mathrm{p}=0.0001)$. A total of $14.9 \%$ of experts and related workers, $10 \%$ of clerical workers, $23.4 \%$ of service workers, $10.4 \%$ of sales workers, $13 \%$ of agriculture and fisheries skilled workers, $1.4 \% 6.9 \%$ of workers in the source and related functions, equipment / machinery operation and assembling worker, $8 \%$ of simple laborers, $4.9 \%$ of soldiers, $13 \sim 5$ times risk factors in service and sales, which is a very high 34-fold increase in workers. This is statistically significant $(\mathrm{p}=0.0001)$ [Table 4]. 
Table 4. Association between industrial workers and occupation characteristics

\begin{tabular}{llll}
\hline & & $n=777(\%)$ & *aOR $(95 \%$ CL) \\
\hline \hline \multirow{5}{*}{ Status of a job } & Full-time & $33(4.2)$ & 1 \\
& Temporary employees & $102(13.1)$ & $2.97(2.25-3.93)$ \\
& Employer with employees & $29(3.7)$ & $2.51(1.25-3.93)$ \\
& Self-employed without employees & $269(34.6)$ & $20.69(9.33-45.86)$ \\
& Unpaid family workers & $344(44.3)$ & $43.83(5.89-325.85)$ \\
\hline pfor trend & $<.0001$ & & \\
\hline & Manager & $11(1.4)$ & 1 \\
& Expert & $116(14.9)$ & $1.99(0.87-4.57)$ \\
& White-collar job & $78(10.0)$ & $0.66(0.32-1.37)$ \\
& Service & $182(23.4)$ & $13.48(3.51-51.74)$ \\
& Salesman & $81(10.4)$ & $4.55(1.96-10.59)$ \\
& Farming, fisheries (skilled workers) & $101(13.0)$ & $33.63(4.22-268.16)$ \\
& Technician & $54(6.9)$ & $0.35(0.18-0.66)$ \\
& Assembler & $54(6.9)$ & $0.18(0.09-0.34)$ \\
& Simple laborer & $62(8.0)$ & $1.24(0.61-2.51)$ \\
& Soldier & $38(4.9)$ & $>999.9(<0.001->999.9)$ \\
\hline pfor trend & $<.0001$ & & \\
\hline
\end{tabular}

\section{DISCUSSION}

In the case of men in the manufacturing industry, the period of work and the working environment tend to be as high as $80 \%$ in less than one year (14). In this study, 17\%, 16\%, and 33\% of new and persistent non-economically active population and reemployed persons are high, respectively. Second, the psychological effect on male manufacturing workers is significant in affecting their health and quality of life, and above all factors related to working environment and working conditions act, and irregular exercise and diet (15). This suggests that the stress of direct work depends on alcohol (43\%) and tobacco (43\%). Third, in terms of the quality of life and the general characteristics of the individual, the analysis of 906 respondents showed that $72 \%$ of respondents answered that they feel "about their own lives" and $63 \%$ in the "behavior that cannot be reversed in the thought of one's own behavior". Lastly, there were 777 workers in the premises and $13.1 \%$ in non-regular workers, $3.7 \%$ in non-regular workers, $34.6 \%$ in self-employed workers without employees, $(44.3 \%)$. Therefore, it is expected that some anxiety factors can cause deterioration of health, which is known to have been reported (16). Another insecure factor is $1 \%$ of managers, which shows that the ratio of non-expertise in manufacturing is high as $23 \%$ of services, $10 \%$ of sales, and $13 \%$ of agriculture and forestry fishery, compared with $14 \%$ of experts and related workers. As a result, the risk increases by 13 to 5 times in services and sales, and by 34 times in agricultural and forestry skilled workers ( $\mathrm{p}$ for trend $=0.0001$ ).

\section{CONCLUSIONS}

As a result, the action is considered to be a factor in worsening health due to the uncertainties of workers in manufacturing a variety of working environments. In the long term, this change in exposure can be seen to have an overall impact not only on individuals but also on society. Therefore, various environment changes are required, the management plan of the workplace should be sought, and the quality of life through leisure allowance will help the production of the product. Finally, we will try to identify the relationship between industrial safety and health legislation and industrial accident disasters, and will play a role as a basic rule for prevention. However, feel the limit of the characteristics of the health and safety and health activities including the individual characteristics of the workplace and the temporal change, but I hope that the health care is managed with various factors.

\section{ACKNOWLEDGEMENT}

This work was supported by a 2-Year Research Grant of Pusan National University.

\section{REFERENCES}

[1] Jeong-Cheol L, Chan-Sik L. Accident Characteristics of Aged Construction Workers. Journal of the Architectural Institute of Korea Structure \& Construction. 2008;24(5):201-8.

[2] Lee H-S, Kim J-W, Kim S-H, Hwang S-K. The Effect of Worker's Job Satisfaction and Turnover Intention of Hospital Welfare. The Korean Journal of Health Service Management. 2012;6(3):107-15.

[3] Rho JK, Yoo KH, Lee YS, Gho YC. A Study on the Sleep Itisorder of a Part of Manufacturing Plant Workers. Korean Journal of Occupational and Environmental Medicine. 1994;6(2):377-83. 


\section{A Study On The Factors Affecting Health And Economic Activities Of Work Environment In}

Manufacturing Industry

[4] McBey K, Karakowsky L. Examining sources of influence on employee turnover in the part-time work context. Career Development International. 2001;6(1):39-48.

[5] Jones MK, Latreille PL, Sloane PJ, Staneva AV. Work-related health risks in Europe: are older workers more vulnerable? Social Science \& Medicine. 2013;88:18-29.

[6] Choi K-Y, Yang K-S. A Study on the Characteristics of Injured Workers Rate and Work Environment of Male Workers for over 40 years. The Korean Journal of Health Service Management. 2016;10(1):131-42.

[7] Ko M-S. Factors Affecting the Level of Self-Perceived Health Recovery among Injured Workers. The Korean Journal of Health Service Management. 2015;9(4):183-96.

[8] Ellingson JE, Gruys ML, Sackett PR. Factors related to the satisfaction and performance of temporary employees. Journal of applied psychology. 1998;83(6):913.

[9] Bermudez E, Mangum JB, Asgharian B, Wong BA, Reverdy EE, Janszen DB, et al. Long-term pulmonary responses of three laboratory rodent species to subchronic inhalation of pigmentary titanium dioxide particles. Toxicological Sciences. 2002;70(1):86-97.

[10] de Jong J, Schalk R. Extrinsic motives as moderators in the relationship between fairness and work-related outcomes among temporary workers. Journal of Business and Psychology. 2010;25(1):175-89.

[11] Park S-K, Cho Y-C. Relationships Between Alcohol Intake and Blood Pressure, Serum Lipids, Liver Function Tests and Obesity Indices in MiddleAged Male Workers. Journal of the Korea Academia-Industrial cooperation Society. 2015;16(5):3323-32.

[12] Pijls LT, Feskens EJ, Kromhout D. Self-rated health, mortality, and chronic diseases in elderly men: the Zutphen Study, 1985-1990. American Journal of Epidemiology. 1993;138(10):840-8.

[13] Sorlie PD, Backlund E, Keller JB. US mortality by economic, demographic, and social characteristics: the National Longitudinal Mortality Study. American Journal of Public Health. 1995;85(7):949-56.

[14] Eberhardt BJ, Shani AB. The effects of full-time versus part-time employment status on attitudes toward specific organizational characteristics and overall job satisfaction. Academy of Management Journal. 1984;27(4):893-900.

[15] Van Dyne L, Ang S. Organizational citizenship behavior of contingent workers in Singapore. Academy of management Journal. 1998;41(6):692-703.

[16] Krausz M, Brandwein T, Fox S. Work attitudes and emotional responses of permanent, voluntary, and involuntary temporary-help employees: an exploratory study. Applied Psychology. 1995;44(3):217-32. 